HERBERT BERNSTEIN \& JOACHIM ZEKOLL

\title{
The Gentleman's Agreement in Legal Theory and in Modern Practice: United States
}

\section{LEGAL THEORY}

A. Deliberate no-law

1. The central issue

'A gentlemen's agreement is an agreement which is not an agreement, made between two persons, neither of whom is a gentleman, whereby each expects the other to be strictly bound without himself being bound at all.'1

This oft-quoted British description fairly accurately reflects the prevailing American attitude towards the concept of gentleman's agreements. In the United States, the term is often used pejoratively and sometimes as an accusation. For example, a plaintiff in a civil rights case may try to prove that the defendants, pursuant to an illegal agreement - mockingly referred to as a "gentleman's agreement"- consented not to hire or promote members of a particular race. ${ }^{2}$ Similarly, the American tobacco industry is accused of having entered into a "gentleman's agreement" some time ago not to disclose the health hazards of smoking and, in particular, the addictive properties of nicotine. ${ }^{3}$ If proven, this so-called gentleman's agreement would, in effect, be a conspiracy by any other name.

Possibly as a result of this ominous usage, there seems to be a certain reluctance to use the term to describe a category of agree-

Herbert Bernstein is Professor of Law, Duke University School of Law.

JOACHIM ZEKOLL is Professor of Law, Tulane University School of Law.

The authors wish to thank Ms. Nadia Nedzel for her able research assistance.

1. Bloom v. Kinder [1958] T.R. 91, quoted in D.K. Allen, England, in Ewoud H. Hondius (ed.), Precontractual Liability: Reports to the XIIIth Congress of the International Academy of Comparative Law 125, at 138 (1991), also attributed to Chemco Leasing Spa v. Rediffusion plc, Queen's Bench Division (Commercial Court), Ominsky, "Counseling the Client on 'Gentleman's Agreements'," 38 Practical Lawyer 25, 26 (1990).

2. See e.g., Bernard v. Gulf Oil Corp., 841 F.2d 547, 552-55 (5th Cir. 1988). For a cinematographic account, see Gentleman's Agreement, directed by Elia Kazan (1947).

3. See, for instance, Meade, "Breaking Through the Tobacco Industry's Smoke Screen," $17 \mathrm{~J}$. Legal Med. 113, 129 at n. 187. 
ments which, without being illegal, opt for "deliberate no- law." Thus the phenomenon is only obliquely addressed in the Restatement (Second) of the Law of Contracts, ${ }^{4}$ and there is but scant discussion of it in the major treatises on contract law. ${ }^{5}$ Nevertheless, the concept of an agreement that, by virtue of the parties' consent, is to be enforced "in honor" only is familiar enough. Under the consent theory of contracts, it can be stated as a principle: Where parties agree completely on all the terms of a normal nominate contract but also clearly and unequivocally agree that this is to produce no legal consequences but is to be binding in honor only, then it will not be legally enforceable. ${ }^{6}$

At this point a distinction will have to be made. Under certain circumstances the "no-law" agreement is understood to be permanent, i.e., the parties do not at all intend to eventually enter into a legally binding contract. In other instances their agreement is only temporarily a "gentleman's agreement," in the sense that, while they do not wish to be legally bound now, they leave open the possibility to become so bound later.

It is extremely difficult to determine, with any degree of certainty, how widespread the use of permanent "no-law" agreements is in actual American business practice. There is an almost impenetrable veil obscuring our view of the facts, because no such agreement will ever surface in a court of law unless the parties differ as to its effect. Thus the case law is of only limited value for our present purposes, ${ }^{7}$ and we must turn to other sources as well. Interestingly, there are publications in the legal literature indicating that in certain industries and throughout certain periods of time "no-law" agreements are or have been used more or less frequently.

The diamond industry is a case in point. On the basis of extensive studies, one author states:

The diamond industry has systematically rejected state-created law. In its place, the sophisticated traders who dominate the industry have developed an elaborate, internal set of rules, complete with distinctive institutions and sanctions, to handle disputes among industry members. ${ }^{8}$

4. See Restatement (Second) of the Law of Contracts (1979) \$21 comment b.

5. See e.g., Joseph M. Perillo, Helen Hadjyannakis, Eric M. Holmes, Corbin on Contracts, vol.1: Formation of Contracts (rev. ed. 1993) \& Suppl. 1997; Samuel Williston, Williston on Contracts (3rd ed. 1979, by Walter H.E. Jaeger); E. Allen Farnsworth, Contracts (2d ed.1990).

6. Wendell H. Holmes, "The Freedom Not to Contract," 60 Tul. L. Rev. 751, 752 \& n. 5 (1986), citing 1A Corbin, Corbin on Contracts $\$ 34$ (1963); 1 Williston, A Treatise on the Law of Contracts $\$ 21$ (Walter H.E. Jaeger, 3d ed. 1957).

7. A search of Westlaw's ALLFED's database for cases using the term "gentleman's agreement" produced 240 cases, none of which contained any substantial discussion of the term.

8. See Lisa Bernstein, "Opting Out Of the Legal System: Extralegal Contractual Relations In the Diamond Industry," 21 J. Leg. St. 115 (1992). 
Following a careful examination of the industry's business practices and dispute settlement mechanisms, the author reaches this conclusion:

By a variety of reputational bonds, customary business practices, and arbitration proceedings, the diamond industry has developed a set of rules and institutions that its participants find clearly superior to the legal system. The industry, as it has been traditionally organized, is able to make and, more important, enforce its own rules. The market is organized to promote the low cost and rapid intraindustry dissemination of information about reputation, which enables it to use reputation bonds to create intraindustry norms that function as a deterrent to breach of contract and a private sanctioning system whose judgments can almost always be enforced completely outside the legal system.

The customs and institutions in the diamond industry emerged for reasons wholly unrelated to shortcomings in the legal system; yet, even as the force of the old enforcement mechanisms of religion and secondary social bonds began to disintegrate, a network of trading clubs, designed to promote the dissemination of information about reputation and socialization among members, emerged to fill the gap. That generations of diamond dealers have clung to nearly identical intraindustry norms in countries with a wide variety of legal rules and institutions suggests that the traditional rules and institutions are likely to be efficient from the perspective of market insiders. In the United States, the traditional rules and institutions endured over time and demonstrated their superiority to the established legal regime.

In the diamond industry, "trust" and "reputation" have an actual market value. As an elderly Israeli diamond dealer explained, "when I first entered the business, the conception was that truth and trust were simply the way to do business, and nobody decent would consider doing it differently. Although many transactions are still consummated on the basis of trust and truthfulness, this is done because these qualities are viewed as good for business, a way to make a profit." ${ }^{\prime 9}$

Outside of the diamond business, there is not likely to be another industry in the United States operating under even remotely the same conditions. And to our knowledge no study comparable to Lisa Bernstein's well-focused and profound research in the world of dia-

9. See Lisa Bernstein, id., at 157. 
mond merchants has as yet been conducted. ${ }^{10}$ There are, however, occasional comments by insiders from other realms of business offering us at least glimpses into the reality of transactions carried out in the form of "no-law" agreements.

Thus, a recent article discussing power purchase agreements among independent power producers makes the point that a significant change has occurred in the American power industry during the last decade. Until the mid-1980's, wholesale transactions pertaining to electric capacity were generally conducted between regulated utilities only. In this environment, "contracts were short and frequently amounted to a gentlemen's agreement."11 In the last 10 years, while more and different participants have entered the market, it seems that transactions have tended to take the shape of more formal and elaborate contracts.

A similar transformation has occurred in the reinsurance market which, as is well known, is constituted on a worldwide, not a national basis. Considerably more companies offer coverage in this market today than in the past. This development has led lawyers to question the continued validity of the doctrine of uberrima fides,${ }^{12}$ as applied to reinsurance relationships. In the course of discussing this issue, authors will often describe the prevailing conditions in the reinsurance market in terms of "gentleman's agreements." ${ }^{3}$ But it is not entirely clear what they mean to say by using this term. In fact, reinsurance transactions have never been seen as "no-law" business deals. While it is true that litigation as well as formal arbitration involving such deals was extremely rare in the past and has proliferated only in recent years, ${ }^{14}$ litigation and arbitration of reinsurance disputes did happen even during the era described as the regime of "gentleman's agreements." Courts and arbitrators were not asked to treat reinsurance transactions as agreements intended to have no legal effect. Rather, in the admittedly rare cases in which a reinsurance dispute was litigated or arbitrated, the parties obviously argued the issues on the assumption that they had made a legally binding

10. The same author's more recent study of contract practices in the grain industry deals with a system of industry-specific default rules and compulsory arbitration rather than "no-law" agreements; see Lisa Bernstein, "Merchant Law in a Merchant Court: Rethinking the Code's Search for Immanent Business Norms," 144 U. of Penn. L. Rev. 1765 (1996).

11. See Eastern Mineral Law Foundation, Proceedings of the $14^{\text {th }}$ Annual Institute, 1993, S 18.02.

12. This doctrine holds that parties to a reinsurance contract owe each other an obligation of acting in "utmost good faith" requiring the reinsured to disclose all facts relevant to the risk involved even if the reinsurer has not inquired about them; see Cohen, DeMasi \& Krauss, "Ueberrimae Fidei and Reinsurance Rescission: Does A Gentlemen's Agreement Have A Place In Today's Commercial Market?," 29 Tort \& Ins. L. J. 602 (1994).

13. See, for example, id.

14. Accord, id. at 602,604 . 
contract. Thus, the meaning of "gentleman's agreement," as used with respect to the reinsurance market of the past, is not the same as that defined above for purposes of this paper. Rather, it is to be understood as just another way of saying that there existed a "reinsurance club"15 with long-term personal relationships based upon trust. It was exactly this kind of relationship that gave rise to the doctrine of uberrima fides in the cases that actually reached the courts.

\section{Other issues}

We will now turn to "no-law-yet" situations in which, as stated before, parties to an emerging agreement, while they do not wish to be legally bound now, leave open the possibility of being so bound later. Obviously, application of the term "gentleman's agreement" to this kind of situation as well as to permanent "no-law"agreements like those in the diamond industry, should not obscure the significant differences between the socio-economic circumstances existing in the two distinct contexts.

Typically, the purpose of producing a writing with a "no-law-yet" clause is that, in the process of complex negotiations, the parties need a memorial recording those points on which they have reached an understanding. In accordance with its intent, such an agreement should not be treated as binding. ${ }^{16}$ The rationale behind this view is that a contract is created only when an offer meets with an acceptance such that both parties have clearly manifested their intent to be bound. ${ }^{17}$ The prevailing view is that in order to encourage and facilitate negotiations, parties' freedom from contract must be protected until such time as they clearly and explicitly agree to create an enforceable contract. ${ }^{18}$ Negotiations are regarded as aleatory in nature: parties negotiate with the knowledge that if they fail to reach ultimate agreement, they will not be bound and thus each bears his own risk should negotiations fail. ${ }^{19}$ In line with this aleatory concept, where parties agree not to be legally bound, the courts will, as a rule, respect their wishes. ${ }^{20}$

15. Id. at 603 .

16. See Farnsworth, "Precontractual Liability and Preliminary Agreements: Fair Dealing and Failed Negotiations," 87 Colum. L. Rev. 217, 250 (1987) discussing various types of preliminary agreements, some of which manifest an intent to be bound, and some of which do not.

17. Wendell H. Holmes, supra n. 6, at 751.

18. See Farnsworth, supra n. 16, at 221 (discussing the "aleatory view" of negotiations) and id. at 263 (parties negotiate with the knowledge that if they fail to reach ultimate agreement they will not be bound). See also Lake, "Letters of Intent: A Comparative Examination under English, U.S., French and West German Law," 18 Geo. Wash. J. Int'l L. \& Econ. 331, 339 (1984).

19. Farnsworth, id. at 263.

20. See Arnold Palmer Golf Company v. Fuqua Industries, Inc., 541 F.2d 584, 586 (6th Cir. 1976) quoting from Corbin's treatise, supra n. 5, as follows: "The courts are quite agreed upon general principles. The parties have power to contract as they 
If an action is brought by one party to enforce an agreement containing a "no-law-yet" clause, the court is likely to respect such clause whether or not it is pleaded by the other party. ${ }^{21}$ In interpreting a contract, the traditional rule is that an interpretation "which gives a reasonable, lawful, and effective meaning to all the terms" is preferred. ${ }^{22}$ Thus, if a written memorial of an agreement contains a "nolaw-yet" clause, a court is likely to consider the clause, regardless of whether the parties themselves bring the clause to the court's attention. Nevertheless, it would be highly unlikely that a party denying liability under an alleged contract would not plead such a clause if there is every reason to expect that a court would regard it as controlling.

In keeping with the parties' intent that the agreement not yet be enforceable, if one of the parties incurs reliance costs, he will only be recompensed if he can demonstrate the existence of circumstances giving rise to one or more specific causes of action. One such argument is that, regardless of the clause, a contract in fact came into existence. A contract in fact or contract implied in fact is one inferred from the conduct of the parties, as evidenced by circumstances and the common understanding of men, as opposed to an express contract which is an actual agreement of the parties stated in distinct and explicit language. ${ }^{23}$ In addition to contract-in-fact, a plaintiff may argue for enforcement or an award of damages based on another cause of action such as promissory estoppel, ${ }^{24}$ misrepresentation, ${ }^{25}$ unjust enrichment, ${ }^{26}$ or equitable estoppel. ${ }^{27}$ It is common for a plaintiff to argue first that a contract (in the form of a bargained-for exchange) existed, and then to argue one or more of the other theories as an alternative (most often promissory estoppel).

As with the pure "gentleman's agreement" discussed above, if a document clearly indicates that it is not to be binding until finalized

please, They can bind themselves orally or by informal letters or telegrams if they like. On the other hand, they can maintain complete immunity from all obligation, even though they have expressed agreement orally or informally upon every detail of a complex transaction. The matter is merely one of expressed intention."

21. See e.g., Empro Manufacturing Co., Inc., 870 F.2d 423, 424 (7th Cir. 1989).

22. Restatement (Second) of Contracts $\$ 203$ (1979).

23. Restatement (Second) of Contracts $\$ 4(\mathrm{a})$ (no difference in legal effect between express contract and contract in fact, the only difference is in the mode of manifesting assent); Farnsworth, Contracts, supra n. 5, at 135.

24. Restatement (Second) of Contracts \$ 90(1) ("A promise which the promisor should reasonably expect to induce action or forbearance on the part of the promisee or a third person and which does induce such action or forbearance is binding if injustice can be avoided only by enforcement of the promise"). The remedy may be limited "as justice requires." Id. Typically, courts grant expectation damages or (rarely) specific performance in applying $\$ 90$.

25. Restatement (Second) of Torts $\$ 525$.

26. Restatement (Second) of Contracts $\$ 345$.

27. Similar to promissory estoppel, but predicated on the defendant's misrepresentation or other misconduct, rather than on a promise. 
in a formal agreement, and the parties do not behave as if the final document is a mere formality, then the "no-law-yet" clause will be respected. ${ }^{28}$ But a mere reference to a "formal agreement to follow" will not be conclusive evidence either that the parties intended not to be bound or that they intended to be bound by the preliminary agreement. ${ }^{29}$

If the language of the agreement or the parties' behavior is ambiguous, indicating that they may have intended to be bound by the agreement despite the "no-law-yet" language, then the court will consider all portions of the agreement as well as the parties' behavior in deciding whether the agreement is enforceable at law. ${ }^{30}$ Some of the factors that may be considered in determining whether the parties intended to be bound only by a formal, signed writing are whether "(1) a party expressly reserved the right to be bound only when a written agreement is signed; (2) there was any partial performance by one party that the party disclaiming the contract accepted; (3) all essential terms of the alleged contract had been agreed upon; and (4) the complexity or magnitude of the transaction was such that a formal, executed writing would normally be expected."31 In such cases, the question of whether the parties intended to be bound amounts to a question of fact, rather than a question of law. ${ }^{32}$

Because of the emphasis on the expressed intent to contract, the traditional view is that a contract is created at the instant of mutual assent, ${ }^{33}$ and that until an enforceable contract has been created, no contract-related rights exist. ${ }^{34}$ This concept of the creation of a contract does not take into account those situations in which an agreement is reached piecemeal through several rounds of negotiations, ${ }^{35}$ nor does it deal well with long-term relationships in which no single document sets up the contracting rules between the parties. ${ }^{36}$ While doctrines such as unjust enrichment and promissory estoppel fill the void to some extent, the common law, as applied in the United States,

28. See Farnsworth, supra n. 16, at 257-60.

29. Id. at 258-59.

30. See e.g., Texaco, Inc. v. Pennzoil Co., 729 S.W. 2d 768, 790-92 (Tex. Ct. App. 1987), award reduced, $107 \mathrm{~S}$. Ct. 1519 (1987). .

31. Id.

32. Palmer v. Fuqua, 541 F.2d at 588, Itek Corp. v. Chicago Aerial Ind. (Itek I), 248 A.2d 625, 627-29 (Del. 1968); Texaco, Inc. v. Pennzoil Co., 729 S.W. 2d 768, 790-92 (Tex. Ct. App. 1987).

33. Wendell H. Holmes, supra n. 6, at 751 .

34. Knapp, "Enforcing the Contract to Bargain," 44 N.Y.U. L. Rev. 673, 674 (1969).

35. Farnsworth, supra n. 16, at 219.

36. See Speidel, "Afterword: The Shifting Domain of Contract," $90 \mathrm{Nw} . U . L, R e v$. 254,255 (1995). 
does not recognize the existence of the duty of good faith and fair dealing until an enforceable contract is created. ${ }^{37}$

The tension created by confrontation of the traditional view of contract formation and modern contractual relationships has been a major subject of discussion among American legal scholars since Grant Gilmore pronounced "The Death of Contract."38 While Gilmore's prediction that the line between tort and contract law would break down ${ }^{39}$ has proven premature because the emphasis on reliance and promissory estoppel has not grown as much as some scholars thought it would, ${ }^{40}$ nevertheless, the concepts of contract in fact and other non-assent-based theories are invoked more frequently than in the past. ${ }^{41}$

Although the line between contract and tort may not have broken down, courts are probably more inclined now to consider the entire course of interactions between the parties in determining the issue of contractual liability in the absence of a binding promise. This includes cases in which language has been used so as to expressly negate the existence of a contract. ${ }^{42}$ This shift towards imposition of contract liability in the face of the denial of a promise has been interpreted by some commentators as a significant shift away from traditional rules. ${ }^{43}$ In addition to considering the context of the parties' dealings and reliance theory as opposed to bargain theory, courts are also more likely to supply material terms omitted in an otherwise enforceable agreement, and are more likely to focus their attention on the presence or absence of good faith and the fairness of an ex-

37. Restatement (Second) of the Law of Contracts $\$ 205$ comment c. (1981); U.C.C. $\S 1-203$; Farnsworth, supra n. 16, at 221. But see Palmieri, "Good Faith Disclosures Required During Precontractual Negotiations," 24 Seton Hall L. Rev. 70, 120 (1993)(arguing for recognition of such a duty). Puerto Rico which, as a mixed civilian jurisdiction, does recognize culpa in contrahendo, regarding it as an application of promissory estoppel. Eric M. Holmes, 3 Corbin: Formation of Contracts $\$ 8.12$, at 117 (1996). Courts in Louisiana, another mixed civilian jurisdiction, have talked about culpa in contrahendo (Davilla v. Jones, 418 So.2d 724 (La. App. 4th Cir. 1982), rev'd. 436 So.2d 507 (La. 1983); Coleman v. Bossier City, 305 So.2d 444, 447 (La. 1974)), but have not clearly adopted it, relying instead on detrimental reliance, a form of promissory estoppel, La. Civ. Code art. 1967.

38. Grant Gilmore, The Death of Contract (2nd ed. 1995), based on lectures delivered in 1970. See also Speidel, supra n. 36, at $254 \& 266$.

39. See Gilmore, id. at 95.

40. See Barnett \& Becker, "Beyond Reliance: Promissory Estopppel, Contract Formalities, and Misrepresentations," 15 Hofstra L. Rev. 443, 495-96 (1987); Pham, "The Waning of Promissory Estoppel," 79 Cornell L. Rev. 1261, 1289 (1994) (promissory estoppel as formulated under $\$ 90$ of the Restatement (Second) of Contracts has not become a primary, independent theory of obligation, instead courts show extreme reluctance to deviate from traditional contract principles).

41. Speidel, supra n. 36 , at 255.

42. See e.g., Sons of Thunder, Inc., v. Borden, Inc., 690 A.2d 575, 1997 Lexis 79 (N.J. 1997); Texaco, Inc. v. Pennzoil Co., 729 S.W. 2d 768, 790-92 (1987); Hoffman v. Red Owl Stores, Inc., 26 Wis.2d 682, 133 N.W.2d 267 (Wis. 1965).

43. See, for example, Speidel, supra n. 36 , at 260-61. 
change. ${ }^{44}$ The result is that the freedom from contract is becoming more restricted: while bargainers may still specify that their's is not (or not yet) a legally binding agreement, their freedom from contractual obligations will be secure only if their actions have been consistent with their expressed intent and with the accepted practices in their industry. ${ }^{45}$

It has been predicted that the shift toward greater enforcement of contract in fact will force contract law doctrine to change accordingly, as classical doctrine has been shown to be insufficient. ${ }^{46}$ While the bargain principle may be easily applied to a negotiated agreement, special rules may need to be developed to provide consistent and fair standards for other types of agreements, such as those created through the use of standard forms and those that arise in the context of a long-term relationship between parties. ${ }^{47}$ Of course, freedom from contract, if regarded as of benefit to society, also needs to be protected, lest the increasing concern for fairness and good faith develop into a paternalistic imposition that in the end will prove deleterious to commerce. ${ }^{48}$ And it has been pointed out that vast inconsistencies characterize the cases in which courts have departed from the traditional consent model of contract liability. ${ }^{49}$ This criticism includes the cases imposing contractual liability in the face of an express clause stating that no legally binding contract is (as yet) being formed.

\section{B. Contextual no-law}

Sometimes a plaintiff may seek recovery on the basis of an arrangement which, from a certain perspective, looks like a contract. Even in the absence of a "no-law" clause, however, the court may conclude from the context of the arrangement that no legally enforceable contract resulted from it, even though an agreement was reached which, on the face of it, was intended to create obligations for the parties.

Agreements between family members have triggered this kind of judicial reaction in a number of cases. More than a hundred years ago, the Supreme Court of Iowa in Miller $v$. Miller ${ }^{50}$ refused to give effect to a well-drafted reconciliation agreement of a married couple which, among other things, by its terms entitled the wife to an an-

44. Id.

45. Wendell H. Holmes, supra n. 6, at 796.

46. Id.

47. See Speidel, supra n. 36 , at 263 .

48. In this sense: Newell, "Will Kindness Kill Contract?," 24 Hofstra L. Rev. 455, 471 (1995)(too much emphasis on good faith in a commercial context leads to "commercial palimony").

49. See Wendell H. Holmes, supra n. 6, at 787-97.

50. 78 Iowa 177,35 N.W. 464,42 N.W. 641 (1887). 
nual payment of $\$ 200$ "for her individual use." The husband's payments were to be made so long as the wife would comply with the reconciliation conditions which included promises of respectful and peaceful behavior. Rather than relying on a lack-of-consideration argument, the court dismissing the case reasoned thus:

It is the genius of our laws, as well as of our civilization, that matters pertaining so directly and exclusively to the home, and its value as such, and which are so generally susceptible of regulation and control by those influences which surround it, are not to become matters of public concern or inquiry.

While the opinion is couched in terms of public policy, the court obviously did not mean to disapprove of reconciliation agreements between husband and wife. These agreements are fundamentally different from other instances in which public policy bars the enforcement of a contract as, for example, a contract on the life of another or a contract in violation of antitrust law. By contrast with such agreements, reconciliation agreements as such are unobjectionable; but the court in Miller found they should not be held binding in law, because this would get the court involved in the internal workings of a marriage which was held to be undesirable. ${ }^{51}$

In other cases, however, American courts have been more inclined to enforce agreements entered into in a family setting. While here, too, a contextual argument could have been made so as to justify non-interference by the legal system, the cases show that the family context does not generally prevent American courts from applying the usual contract analysis.

In Hamer $v$. Sidway, ${ }^{52}$ a decision from the same period as the Miller opinion, an uncle had promised his nephew $\$ 5,000$ if the nephew would refrain from drinking, using tobacco, swearing, and playing cards or billiard for money until he became 21 years of age. Finding that a legal benefit was conferred upon the uncle, and that the consideration requirement was thus met, the court held that an enforceable contract had been concluded. The fact that the promise had been made among close relatives and on the occasion of the golden wedding of the promisor's parents (who were also the promisee's grandparents), is mentioned in the opinion but treated as irrelevant. Also the non-commercial, obviously pedagogical purpose of the

51. Even today American courts are extremely reluctant to enforce agreements regulating an ongoing marriage relationship in matters other than property and support; for details, See Graham, "The Uniform Premarital Agreement Act and Modern Social Policy: The Enforceability of Premarital Agreements Regulating the Ongoing Marriage," 28 Wake Forest L. Rev.1037, at 1043-49 (1993). For profound criticism of this attitude, see the dissent by Ass. Justice Poche in Borelli v. Brusseau, 12 Cal.App. $4^{\text {th }} 647,16$ Cal.Rptr. $2 d 16$ (Cal. Ct. App.1993).

52. Hamer v. Sidway, 124 N.Y. 538, 27 N.E. 256 (1891). 
promise did not prompt the court to conclude that this was an extralegal arrangement, not enforceable in law.

Commentators, however, have characterized cases of this kind as "bait" situations. ${ }^{53}$ As a subspecies in this category, Hamer and similar cases ${ }^{54}$ have been described as involving promises "by a family member with money to influence the lives of those without it." $55 \mathrm{An}$ other subspecies comprises agreements obligating one party to provide for an elderly and/or sick family member on the promise of compensation, frequently in the form of benefits to be derived from the promisor's estate upon his/her death. In both types of cases, American courts have generally been quite receptive to the promisee's call for legal protection. ${ }^{56}$

Most of the "bait" cases are litigated not between the family members originally affected, but between an executor (or administrator), on the one hand, and a family member of the decedent (or even an assignee of such family member), on the other. This fact may help to explain why in these cases there is virtually no discussion of the family context as a possible reason for viewing the express or implied promise of payment as not binding in law, but "in honor" only. In addition, it can be argued that care for the elderly by a family member (or, in some of the cases, a third person) ${ }^{57}$ is a matter of serious concern to the public which should not be left to extrajudicial sanctions or to an enforcement in the "interior forum, the tribunal of conscience."58 More generally speaking, it has been observed that American courts today show a greater willingness to allow parties to a marriage or other family relationship freedom to customize their relationship by making legally enforceable agreements..$^{59}$

\section{Modern Practice}

Before discussing in somewhat greater detail specific cases dealing with agreements containing "no-law" or "no-law-yet" clauses, it is important to note that United States law is not uniform; the fifty states have fifty different bodies of law. Even the statement that the U.S. is a common-law country must be qualified, as Louisiana and the commonwealth of Puerto Rico are more accurately described as mixed-civilian jurisdictions. The diversity of interpretation of prom-

53. See, for example, Stewart Macaulay, John Kidwell, William Whitford \& Marc Galanter, Contracts: Law in Action, Vol. I (1995) at 290-302, 326, 343.

54. See, for example, Devecmon v. Shaw, 69 Md. 14, 14 A. 464 (1888).

55. See Macaulay et al., supra n. 53, at 290.

56. For a leading case of the second kind, see Davis v. Jacoby, $1 \mathrm{Cal} .2 \mathrm{~d} 370,34 \mathrm{P}$. 2d 1026 (1934).

57. For a discussion of such cases, see Macaulay et al., supra n. 53, at 365-70.

58. See Mills v. Wyman, 3 Pick. [20 Mass.] 207 (1825).

59. See Farnsworth, Contracts, supra n. 5, at 364-67. But see also the cases discussed by Graham, supra n. 51 . 
issory estoppel is itself so broad that a major new treatise spends nearly half of one volume on the topic, discussing the law of each state individually. ${ }^{60}$

\section{A. Stand-alone no-law clauses}

1. "No-law" clauses in firm commitment underwriting

'No-binding-effect' clauses are commonly utilized in securities underwriting, where the use of such documents is widely accepted. The most common arrangement is firm commitment underwriting in which the underwriting group agrees to purchase the securities from the issuer. ${ }^{61}$ The agreement commonly contains a "market out" clause excusing the underwriters from the obligation to purchase in the event of a substantial change in the issuer's financial condition. Moreover, until the eve of the offering, the issuer and underwriter operate under a non-binding letter of intent, which is converted into a binding agreement for the sale of securities only after the Securities and Exchange Commission issues its approval of the offering. ${ }^{62}$ For example, in one case, the plaintiff was to act as principal underwriter for a proposed offering of the defendant issuer's common stock, ${ }^{63}$ and the letter of intent provided that "it is expressly understood that no liability or obligation of any nature whatsoever is intended to be created as between any of the parties hereto." When the defendant issuer attempted to withdraw from the (gentleman's) agreement, the underwriter sued to enforce the letter of intent as a binding agreement or, alternatively, to obtain restitution for the value of its services performed and for costs expended.64 The court rejected both claims, based on the clear and unambiguous language of the letter of intent, as well as the customary usage of letters of intent in the securities industry which made it clear that such documents are only regarded as tentative expressions of intention. ${ }^{65}$ This case, while almost 30 years old, can be seen as an unequivocal contemporary affirmation of the consent theory of contracts and, by the same token, as a clear recognition of the "no-law" effect of a "gentleman's agreement."

\section{Comfort letters}

Generically speaking, a comfort letter is an instrument written by a third party and is designed to encourage the creation of an

60. Eric M. Holmes, 3 Corbin, supra n. 37 , at $\$ 8.12$.

61. Thomas Lee Hazen, The Law of Securities Regulation $\$ 2.1$ (3d ed. 1996).

62. Id.

63. Dunhill Securities Corp. v. Microthermal Applications, Inc., 308 F. Supp 195, 197 (S.D.N.Y. 1969), discussed in Wendell H. Holmes, supra n. 6, at 777-79.

64. Wendell H. Holmes, supra n. 6, at 778.

65. Id. 
agreement between two other parties. ${ }^{66}$ Most comfort letters are not, strictly speaking, gentleman's "agreements," because the drafter of the letter, by making a unilateral statement, does not become a party to any agreement and is also, of course, not making a promise or obligating herself in any way. However, sometimes a comfort letter leads to the subsequent involvement of the drafting party in the agreement itself, despite that party's original intent that the letter not create any obligations. Such comfort letters can thus generate enforcement hazards similar to those we have described with other types of gentleman's agreements.

Comfort letters are often drafted by a parent company and are aimed at encouraging a lending institution to issue credit to a subsidiary. ${ }^{67}$ The drafter of the instrument wants to avoid incurring liability on the parent company's part for the non-performance of the potential debtor, the subsidiary. Yet, at the same time, the parent wishes to encourage the potential creditor, the financial institution, to enter into a legally binding transaction. ${ }^{68}$ In other words, a comfort letter of this type is aimed at being something more than a letter of introduction, but something less than a guaranty or suretyship commitment. ${ }^{69}$ Some commentators have found that such instruments "contain language that could induce reliance while they attempt to disclaim any liability as a guaranty;" and this has led them to describe such comfort letters as "inconsistent" and "internally repugnant."70 This negative view of comfort letters closely resembles the attitude vis-a-vis gentleman's agreements expressed by the English court quoted at the outset of this paper.

As a consequence of such an attitude and to the chagrin of the drafters of such comfort letters, those documents may sometimes lead

66. See DiMatteo \& Sacasas, "Credit and Value Comfort Instruments: Crossing the Line from Assurance to Legally Significant Reliance and Toward a Theory of Enforceability," 47 Baylor L. Rev. 357, 362-365 (1995)(some such comfort letters include the "validity agreement" in asset-based financing, letters of intent or understanding in real estate leasing and business purchases, and "black box letters" used in the transfer of intellectual property). A comfort letter may be written by a third party to assure a potential creditor that the prospective debtor is credit-worthy. DiMatteo, "The CISG and the Presumption of Enforceability: Unintended Contractual Liability in International Business Dealings," 22 Yale J. Int'l. L. 111, 114 (1997). It may also be a letter of professional opinion, such as the "due diligence" letter used by accountants in the securities industry. DiMatteo \& Sacasas, at 362 \& n.21. Or a comfort letter may be in the form of an attorney's letter designed to assure a potential purchaser that a particular document is enforceable. Sacasas \& Wiesner, "Comfort Letters: The Legal and Business Implications," 104 Banking L.J. 313, 313 (1987).

67. Sacasas \& Wiesner, preceding id., at 313,317 citing, e.g., Banque de Paris et des Pays-Bas v. Amoco Oil Co., 573 F. Supp. 1464 (S.D.N.Y. 1983); Barclays Bank of New York v. Goldman, 517 F. Supp. 403 (S.D.N.Y. 1981); State of North Carolina ex rel. Utilities Commission v Edmisten, 333 S.E.2d 453 (N.C. 1981); DiMatteo \& Sacasas, preceding id., at 366-67.

68. Id.

69. Sacasas \& Wiesner, supra n. 66 , at 313.

70. DiMatteo, supra n. 66, at 114 . 
to liability, irrespective of the drafters intent. In principle and consistent with other types of gentleman's agreements, courts generally view comfort letters as unenforceable. ${ }^{71}$ The parent company, however, may find itself held liable as a guarantor when a court considers the letter in the context of the whole relationship among the three parties and finds it to be part of an implied contract. ${ }^{72}$

As with letters of intent, the enforceability of a comfort letter depends on a number of factors, the first being the language of the instrument itself. An intent on the part of the drafter to be bound as guarantor is likely to be found if the instrument, despite the fact that it calls itself a 'comfort letter,' contains operative language such as 'guaranty,' 'contract' or other words of promise. ${ }^{73}$ The more detailed the instrument, the more likely a court will be to find it indicative of an intent to contract. ${ }^{74}$ (In order to avoid such perils, comfort letters are often drafted as vaguely and as broadly as possible). ${ }^{75}$

In addition to the language of the instrument itself, the context in which the comfort instrument was written and other external factors may lead a court to find that the drafter assumed the role of guarantor. One such factor is the sophistication of the parties and whether they sought legal advice as to the meaning and legal significance of the comfort instrument. ${ }^{76}$ Oral representations and the parties' prior dealings may also affect enforceability: one party may argue that the instrument was part of the contractual relationship between lender and borrower, not merely tangential to it. ${ }^{77} \mathrm{An}$ instrument is likely to be enforceable if it is customarily viewed in the particular trade or profession at issue as legally binding. ${ }^{78}$ Finally, a court may scrutinize the parties' reasons for using the comfort instrument, as well as the role that the instrument played in their agreement. If the recipient of the comfort letter reasonably relied on terms given or implied by the instrument, then that comfort letter's statements, even if promisory language has been avoided, may be held enforceable under a theory of promissory estoppel or detrimental

71. Id. at 367.

72. Sacasas \& Wiesner, supra n. 66, at 321-22 discussing Banque de Paris, 573 F. Supp. at 1473; Barclays Bank, 517 F. Supp. at 406.

73. DiMatteo \& Sacasas, supra n. 66, at 381.

74. Id., at 383 .

75. Id., at 385. See also id. quoting Hermann, "Real Comfort in a Comfort Letter," Fin. Times, Feb. 4, 1988: "Comfort letters are a species of those ambiguous declarations which negotiators often use to save a deal threatened by lack of agreement on an important point. ... It is a lawyer's cover-up of a disagreement. The lawyer keeps his fingers crossed and prays that there may never be litigation over the meaning of his handiwork."

76. Di Matteo \& Sacasas, supra n. 66, at 392-94.

77. Id. at 394-396, discussing Cortec Industries v. Sum Holdings, L.P., no. 90C0165, 1994 U.S. Dist. LEXIS 1917 (S.D.N.Y. Feb 23, 1994); 1994 WL 722708 (S.D.N.Y)(Not reported in F. Supp.).

78. Id. at $396-97$. 
reliance even though the drafter had good reasons for wanting to avoid a formal guaranty. ${ }^{79}$

Thus, on a strictly doctrinal level, the reasons for holding a comfort instrument enforceable under U.S. common law can be seen as consistent with those for (sometimes) enforcing other gentleman's agreements: The language used in an instrument alone will not determine whether it is binding in law or "in honor only," rather the manifested intent of the parties and doctrines such as promissory estoppel need to be considered as well.

\section{Non-competition agreements}

Two types of competition agreements bear mention. First, noncompetition agreement used by employers to prevent employees from opening competing businesses after leaving their employ are rarely drafted as a gentleman's agreement. To the contrary, an employer wants such clauses to be enforceable. In general, such clauses are valid only to the extent that they are reasonable. State statutes often require them to be limited both as to time and geographic area. ${ }^{80} \mathrm{Sec}-$ ond, non-competition agreements between business entities tend to be violative of anti-trust laws. The problems thus raised by this type of agreement fall outside the scope of this project.

\section{Pre-contractual agreements}

At a certain point in the course of contract negotiations, the parties may find it helpful to reduce the result of the bargaining process to a writing. They may even make a public announcement to the effect that they have reached an "Agreement in . Principle," and yet when an enforcement of it is later sought by one party, the other will probably argue that no legally binding contract was concluded. In some instances, a "no-law-yet" clause may have been included in the writing.

Whether a preliminary agreement is described as an "Agreement in Principle," a "Letter of Intent," or by other similar terms, this designation alone will not decide the enforcement issue. If it contains a "no-law-yet" clause, even that clause is not conclusive. It will only be considered as evidence suggesting that the parties agreed not to be bound yet. "The parties are masters of their affairs. They may elect not to be bound by writings, however formal; they also may elect to be bound by writings that call for subsequent memorials." 81 Deter-

79. DiMatteo \& Sacasas, supra n. 66 , at 397-99.

80. See e.g., La. Rev. Stat $\S 23: 921$ (all contracts or agreements restraining lawful professions are null and void, employee non-competition clauses not to exceed 2 years from termination of employment and only within specified parish or parishes); Or. Rev. Stat $\$ 653.295$ (similar).

81. Skycom Corp. v. Telstar Corp., 813 F.2d 810, 814 (7th Cir. 1987). 
mining the parties' actual agreement requires an objective approach which focuses on the parties' words, written and oral, as well as their actions. ${ }^{82}$

In a commercial context, what typically happens is that two firms reach an accord on various terms of their transaction and sign what they intend to be a preliminary document memorializing those agreed-upon terms and titled a "Letter of Intent" or an "Agreement in Principle." If the deal later collapses, one of the parties may sometimes claim that the preliminary document is itself legally binding and thus enforceable. ${ }^{83}$

In the United States, often such cases develop out of failed merger attempts. In one case, the court found no agreement was intended because the language contained in the letter of intent indicated that the merger would be binding only once incorporated in a formal, definitive agreement and approved by both shareholders and the board of directors. ${ }^{84}$ In another failed-merger case, the court similarly respected an "agreement in principle" that referred to a future "formal agreement" and additionally contained two clauses giving the defendant the right to back out. ${ }^{85}$ In yet a third case, the court examined facts and circumstances surrounding a failed merger attempt. ${ }^{86}$ Although it contained a somewhat contradictory clause stating that the parties intended to proceed in good faith in the negotiation of a binding definitive agreement, the Letter of Intent provided expressly that it was "not intended to create, nor do you or we presently have any binding legal obligation whatever in any way relating to such sale and purchase." 87 All three cases held that the preliminary agreements lacked the intent to be bound, thereby honoring the "no-law-yet" clauses.

In contrast to these three cases, however, in Arnold Palmer Golf Co. v. Fuqua Industries, Inc., the appellate court reversed a trial court's grant of summary judgment to the defendant in a failed merger case. ${ }^{88}$ In this case, a six page Memorandum of Intent that looked forward to the preparation of a final agreement, and also stated expressly to be subject to approval by the board of directors was held to be not clearly unenforceable. ${ }^{89}$ Prior to calling the deal off, the president of the purchasing company, Fuqua, had released a statement to the press indicating that the parties had agreed to coop-

82. See id.

83. Empro Manufacturing Co., Inc. v. Ball-Co. Manufacturing, Inc., 970 F.2d 423, 424 (7th Cir. 1989).

84. Empro, 870 F.2d at 424.

85. Skycom, 813 F.2d at 814 .

86. Schwanbeck v. Federal-Mogal Corp., 31 Mass. App. Ct. 390, 578 N.E.2d 789

(Mass. App. 1991).

87. Schwanbeck, 31 Mass. App. Ct. at 393.

88. 541 F.2d 584 (6th Cir. 1976).

89. See Palmer v. Fuqua, 541 F.2d at 587-90. 
erate in a joint enterprise. ${ }^{90}$ Such facts indicated to the reviewing court that the parties may have intended to be bound, despite the language of the Memorandum of Intent, and that because of the presence of this issue of material fact, summary judgment was inappropriate. ${ }^{91}$

The most spectacular and well-known of such cases, however, was Texaco, Inc. v. Pennzoil Co., in which the jury found that an "Agreement in Principle" containing a no-law-yet clause was not so incomplete as to preclude the formation of a contract because of the parties' extended negotiations and because the parties had reached agreements on most of the essential terms. ${ }^{92}$ In cases such as Texaco, the issue of whether a particular preliminary agreement amounts to an implied contract is very much subject to the facts of the individual case, and therefore, under the American system, it is frequently determined by a jury. It would be very interesting, but is at the same time quite difficult to ascertain what impact the Texaco decision has had on the behavior of commercial actors concerned about the enforceability of such preliminary agreements, in particular in the context of mergers and acquisitions.

\section{B. Collateral no-law clauses}

\section{Employment Relationship}

In the merger environment and in other cases where a preliminary agreement includes a "no-law-yet" clause, such clause functions as a stand-alone rather than as a collateral "no-law-clause." If the clause is honored by a court, there is no contract to be enforced. By contrast, in the employment context we encounter "no-law" clauses which are meant to affect only a particular aspect of the employment relationship while the legally binding character of the basic contract between the parties remains intact.

Two types of employee agreements are frequently drafted with clauses designed to make them into gentleman's agreements: (1) employee benefit and pension plans and (2) promises dealing with termination policies, as delineated in employment manuals. Inducements such as pensions, death benefits, severance allowances, "Top Hat" deferred pay ${ }^{93}$ and post-retirement medical insurance are used by em-

90. Palmer v. Fuqua, 541 F.2d at 587.

91. Palmer v. Fuqua, 541 F.2d at 590. See also Itek Corp. v. Chicago Aerial, 248 A.2d 625 (Del. 1968).

92. Texaco, Inc. v. Pennzoil Co., 729 S.W. 2d 768, 790-92 (Tex. Ct. App. 1987), affd in substance. $107 \mathrm{~S}$. Ct. 1519 (1987). Since this case was analyzed by Daniel C. Turack, in Hondius (ed.), supra n. 1 , at $333,335-36$, it will not be further discussed here.

93. A "Top Hat plan" is a "plan which is unfunded and is maintained by an employer primarily for the purpose of providing deferred compensation for a select group of management or highly trained employees." In re New Valley Corp., 89 F.3d 143, 148 (3rd Cir. 1996). 
ployers to attract and retain loyal and productive employees. On the other hand, however, employers do not want to be obligated to maintain some of these benefits should they become financially or otherwise unfeasible or unattractive to the employer. ${ }^{94}$ Consequently, employers' literature describing these benefits often contains a disclaimer stating that the employer may amend or terminate the plan unilaterally. ${ }^{95}$ Such disclaimers are intended to give the plan the nature of a gentleman's agreement.

An employment manual usually does not describe a benefit plan, instead it is intended to assure employees that they will be fairly treated, and often contains a clause mandating reference of disputes to an administrative process or arbitration. As with a benefit plan, an employment manual may also contain a disclaimer. ${ }^{96}$ The purpose of such disclaimers is to make certain that the employment-atwill doctrine applies, thus giving the manual the character of a gentleman's agreement (except for any arbitration provision). Under the employment-at-will doctrine of American common law, an employer may discharge an employee for "good cause, for no cause, or even for a wrong cause, without incurring liability for wrongful discharge."97 Just as the employee is free to quit at any time, so the employer must be free to dismiss at any time. ${ }^{98}$

In the hope of generating its employees' good will, the employer may do its best to keep its word, but typically does not want to be contractually bound by promises given in benefits plans or employee manuals. Several factors may operate to make such promises enforceable, including state or federal statutory law as well as the doctrines of implied contract, promissory estoppel, and others.

\section{(1) Pension and welfare benefits plans}

With regard to pension and welfare benefits plans, in 1974 Congress passed the Employee Retirement Income Security Act (ERISA), based on a policy concern that millions of employees depend on the security and soundness of such plans. ${ }^{99}$ ERISA's broad scope covers most employee welfare benefit plans (including medical and other

94. Wendell H. Holmes, supra n. 6 , at 758 .

95. See e.g., In re New Valley Corp., 89 F.3d at 147 ("The Board of Directors may amend or terminate the Plan at any time for any reason and thereafter Participants and their estates and dependents shall have only such rights under the Plan, if any, as shall be specifically provided for the Board of Directors under the Plan as amended or terminated.")

96. See e.g., Morriss v. Coleman Co., Inc. 241 Kan 501, 504, 738 P.2d 841, 844 (Kan. 1987)("The purpose of this manual is to provide all employees through written reference, a better understanding of our privileges and obligations which are an inherent part of our employment. Nothing in this policy manual should be construed as an employment contract or guarantee of employment.").

97. Morriss, 738 P.2d at 845 .

98. Id.

99. 29 U.S.C. $\S 1001(a)$. 
benefits) and pension plans, ${ }^{100}$ with a few exceptions. ${ }^{101}$ ERISA sets minimum requirements of disclosure and standards of conduct for employers and grants employees the power to enforce those standards through corresponding private causes of action. ${ }^{102}$ Since its inception, ERISA law has become a highly complex and intricate body of federal law.

One of Congress's main goals in passing ERISA was to set standards for vesting of pension plans. ${ }^{103}$ When a participant has a vested right to his pension, that right is "unconditional, and legally enforceable against the plan," 104 and therefore cannot be a mere gentleman's agreement. Congress enacted minimum vesting standards to protect employees who are laid off or discharged before retirement age, ${ }^{105}$ but ERISA does not require automatic vesting of welfare benefit plans. ${ }^{106}$ By law, a pension plan must begin by providing that an employee's right to his normal retirement benefit is twenty percent vested after three years of service. Vesting gradually increases thereafter until an employee's rights are one hundred percent vested after seven years. ${ }^{107}$ Until and unless a welfare benefit plan or pension plan is vested; ${ }^{108}$ however, an employer has the right to terminate or unilaterally amend the plan at any time. ${ }^{109}$ Thus, until vesting, a plan may have the nature of a gentleman's agreement, and a disclaimer may protect the employer.

As may be expected, nothing in ERISA forbids or prevents an employer from agreeing to vest employee welfare benefits earlier than mandated by statute, or from waiving the employer's freedom to unilaterally terminate or amend the pension plan prior to vesting, thus converting a gentleman's agreement into a legally enforceable one. ${ }^{110}$ As with the examples discussed previously, an employer's agreement to vest early may be express or implied. The employer

100. 29 U.S.C. $\$ 1002(3)$.

101. 29 U.S.C. $\$ 1003$ (plans excepted include those established by governments, churches, and plans maintained solely for the purpose of complying with other laws such as workmen's compensation).

102. 29 U.S.C. $\S 1001,1002(a)(1)$.

103. Stephen R. Bruce, Pension Claims: Rights and Obligations 187 (2nd ed. 1993)(citing 2 ERISA Leg. Hist. 1773 (Sen. Hartke).

104. Id. (Citation omitted). See also Black's Law Dictionary 1564 (6th ed. 1990)("Right that employee acquires to various employer-contributed benefits after having been employed for a requisite period of time.").

105. Bruce, supra n. 103, at 187-89.

106. Griffs, "ERISA's Dark Side: Retiree Health Benefits, False Employer Promises and the Protective Judiciary," 9 DePaul Bus. L. J. 305, 305 (1997).

107. 29 U.S.C. $\$ 1053$.

108. Vesting: A vested right is one that is complete and consummated, and of such character that it cannot be divested without the consent of the person to whom it belongs, and is no longer open to controversy. See id.

109. 29 U.S.C. $\& 1132$ (a)(1)(B).

110. Schonholz v. Long Island Jewish Medical Center, 87 F.3d 72, 77 (2nd Cir. 1996). 
may expressly agree to vest through formal documents or in a memorandum sent to employees. ${ }^{111}$

To determine whether a promise to vest is enforceable either as a contract implied in fact or under the doctrine of promissory estoppel, courts examine the language contained in collective bargaining agreements, insurance agreements, and all pamphlets issued by an employer to determine whether a disclaimer asserting that the benefit is a mere gentleman's agreement is contradicted by other language vesting rights in employees. For example, in one recent case, the court found that an employer had unambiguously granted lifetime benefits to retirees in a Shutdown Agreement, ${ }^{112}$ despite the disclaimer included in an insurance booklet allowing the employer to change the coverage. ${ }^{113}$ In another recent case, the court found that language reserving the company's right to amend or terminate top hat plans (which are exempt from ERISA's substantive requirements) ${ }^{\mathbf{1 1 4}}$ "at any time for any reason" was ambiguous, and was mere boiler-plate language contradicted by oral promises to the employees, who were entitled to rely on such promises. ${ }^{115}$ Promises of welfare benefits and pensions made in the spirit of gentleman's agreements may be enforceable under standard theories of contract and promissory estoppel even if not already enforceable under ERISA law.

\section{(2) Termination policy promises}

In the employment context, gentleman's agreements may be generated by the employment contract itself as well as by pension and benefits plans. As was discussed above, the general presumption is that employment can be terminated at-will.116 Because either party may terminate the relationship for any reason at any time, suits for wrongful discharge are generally precluded.

State and federal statutes modify the at-will presumption by "limit[ing] an employer's ability to terminate an employee on the ba-

111. Id.

112. A Shut Down Agreement is a type of insurance benefit and may represent a portion of a collective bargaining agreement providing for continuation of certain benefits in the event the employer must cease operations. See Diehl v. Twin Disc, Inc., 102 F.3d 301, 302-03 (7th Cir. 1996).

113. Diehl v. Twin Disc, Inc., id. at 307.

114. 29 U.S.C. 1051(2).

115. In re New Valley Corp., 89 F.3d 143, 150 (3rd Cir. 1996). See also Schonholz v. Long Island Jewish Medical Center, supra n. 110 (denial of plaintiff's claim reversed in part and remanded: severance plan benefits may be enforceable under theory of promissory estoppel).

116. See e.g., Morriss v. Coleman, 738 P.2d at 845 (presumption of doctrine); Johnson v. Morton Thiokol, Inc., 818 P.2d 997, 1000 (Utah 1991)(same); Hartbarger v. Frank Paxton Co., 115 N.M. 665, 857 P.2d 776, 779 (N.Mex. 1993)(same); Toussaint v. Blue Cross \& Blue Shield of Michigan, 408 Mich 579, 292 N.W.2d 880, 884 (Mich 1980)(same); Continental Air Lines, Inc. v. Keenan, 731 P.2d 708, 711 (Colo 1987). But see Wooley v. Hoffmann-LaRoche, Inc., 99 N.J. 284, 491 A.2d 1257, 1259-60 (N.J. 1985)(express employment contract creates an other than at-will relationship). 
sis of race, color, religion, sex, national origin, age, and handicap."117 Retaliatory discharge in violation of public policy may also limit the at-will presumption. ${ }^{118}$ Additionally, however, the at-will presumption may be limited where an employee argues another cause of action such as implied-in-fact contract, ${ }^{119}$ promissory estoppel, ${ }^{120}$ or breach of the duty of good faith and fair dealing. ${ }^{121}$

For example, a disgruntled former employee typically alleges that the employer in fact agreed to dismiss his employees only for cause, and that his dismissal was unjustified and in breach of this promise. The employer points to a disclaimer clause in a handbook, or some other such proof that she did not intend to give up her right to dismiss for any reason, (and that any statement to the contrary was clearly intended to be a gentleman's agreement). ${ }^{122}$ The employee must then show that the employer's statements were sufficiently definitive to establish an affirmative agreement to terminate only for cause through the use of employee handbooks, company manuals, bulletins, oral statements, and the employer's course of conduct. ${ }^{123}$ Alternatively, under promissory estoppel, the employee may argue that the termination procedures detailed in the handbook or promised by the employer should be enforced because the employer should have expected such reliance, the employee did rely on those promises to his detriment, and injustice can only be avoided by the enforcement of those procedures. ${ }^{124}$ As another alternative, some jurisdictions recognize the doctrine of good faith and fair dealing as applicable to terminable-at-will contracts, allowing employees to argue that while an employer needs flexibility in the fact of changing circumstances and control over its work force, any decision to termi-

117. See e.g., Civil Rights Act of 1964, 42 U.S.C. $\$ 2000$ e-2(a)(1); Utah Code Ann. $\S 34-35-6$ (cited in Johnson v. Morton Thiokol, 818 P.2d at 999n.7). See also 42 U.S.C. $\S 12101$ \& f. (Equal Opportunity for Individuals with Disabilities Act).

118. Hartbarger, 857 P.2d at 779 (citing Melnick v. State Farm Mut. Auto. Ins. Co., 106 N.M. 726, 730, 749 P.2d 1105, 1109, cert. denied, 488 U.S. 822, 108 S. Ct. 67, 102 L. Ed. 2d 44 (1988).

119. Hartbarger, 857 P.2d at 779; Sorenson v. Kennecott-Utah Copper Corp, 873 P.2d 1141,1144 (Ct. App. Utah 1994); Patrick v. Painesville Commercial Properties, Inc., 99 Ohio App.3d 360, 650 N.E. 2d 927 (11th Dt. Ct. App Ohio 1994).

120. Patrick, 99 Ohi App.3d at 363.

121. Sorenson, 873 P.2d at $1144-45$.

122. See e.g., Orback v. Hewlett-Packard Co., 97 F.3d 429, 432 (10th Cir. 1996) (internal policy guidelines manual did not create an implied contract to follow the detailed disciplinary and termination procedures it contained because the manual was an outline and guide to managers and did not overcome Colorado's presumption that employment contracts are terminable at-will); Kastner v. Blue Cross and Blue Shield of Kansas, Inc., 21 Kan. App.2d 16, 894 P.2d 909(Ct App. Ka 1995); Johnson v. Morton Thiokol, 818 P.2d at $1003 \mathrm{n} .28$ (list of disclaimer cases preventing terms of employee manual from being considered terms of an employment contract).

123. Sorenson, 873 P.2d at 1146.

124. See e.g., Continental Air Lines, Inc. v. Keenan, 731 P.2d 708, 712 (Colo. 1987); Weiper v. W.A. Hill \& Assoc., 104 Ohio App.3d 250, 260, 661 N.E.2d 796, 803 (Ohio Ct. App. 1995). 
nate an at-will employee should be made in good faith. ${ }^{125}$ With both pension and welfare benefits agreements and employment-at-will contracts, there is a tendency on the part of courts to examine disclaimers carefully and interpret them narrowly out of concern for employees whose bargaining positions typically lack strength. ${ }^{126}$

\section{Conclusions}

Based on our by no means exhaustive research, we can venture a few tentative conclusions regarding the theory and practice of "gentleman's agreements" in the United States.

First, there are indeed certain industries operating on a deliberately chosen "no-law" transaction basis. Second, a necessary condition for the smooth and efficient operation of business on such a basis appears to be the existence of long-term bonds of trust between market participants, such as can be found in the diamond industry. Third, while such trust relationships are a necessary condition for the use of "no-law" transactions, they do not always constitute a sufficient condition, as evidenced by the reinsurance market of the past in which so-called gentleman's agreements were in fact seen, by the participants, as legally binding contracts in the cases where litigation or arbitration occurred. Fourth, this makes it likely that the exclusion of legal remedies under "gentleman's agreements," in the strict sense used in this paper, presupposes certain conditions that encourage compliance with the terms of business agreements in most cases even in the absence of legal sanctions. These conditions include loss of reputation, rapid communication of reputation information, and the attendant threat of exclusion from the market. ${ }^{127}$

But even in the absence of the above conditions business transactions are sometimes carried out under a "no-law" agreement. And the question arises: Why is that done? In a study conducted more than 35 years ago, Stewart Macaulay interviewed businessmen on the "Use and Non-Use of Contract in the Manufacturing Industry"128 and found that often the interviewees took an indifferent or even hostile attitude toward the whole idea of contracts. Lawyers who try to

125. Fortune v. National Cash Register Co., 373 Mass. 96, 364 N.E.2d 1251 (1977). But see Morriss v. Coleman Co., Inc., 738 P.2d at 851 (Ka. 1987)(rejecting applicability of good faith standard as stated in Restatement (Second) of Contracts $\$ 205$ to employment-at-will contracts and listing both jurisdictions that accept and those that reject the applicability of the doctrine).

126. See generally Griffs, supra n. 106. See e.g., Hodgkins v. New England Telephone Co., 82 F.3d 1226, 1231 (1st Cir. 1996) (Despite a disclaimer giving the company sole, exclusive and complete discretion, a promise to pay employees for costsaving ideas was not necessarily unenforceable; See also McIlravy v. Kerr-McGee Coal Corp., 74 F.3d 1017 (10th Cir. 1996).

127. For more details, see Lisa Bernstein, supra n. 8, at 132-35.

128. See 9 Practical Lawyer 14 (Nov. 1963), See also id., "Non-Contractual Relations in Business: A Preliminary Study," 28 Am. Soc. Rev. 55 (1963). 
"work out all the details" were seen as potentially ruining a good deal because the act of mentioning all the horrible things that can happen may scare off the other side. Also, setting up a contractual relationship may lead to performance to the letter of the contract most narrowly construed thus losing the desired "flexibility." It is not unlikely that reasons of this kind are still powerful motives for many American business people who do forego the use of formal contracts in their conduct of certain transactions. From a comparative perspective it is interesting to note that the paradigm of a contract in the minds of those interviewed by Macaulay, is a very detailed, carefully drafted document addressing a great variety of contingencies which may never in fact happen. Indeed, in contrast with the practice in many other countries, American contract practice tends to produce this kind of elaborate piece of legal draftsmanship, and one of the reasons for this prolixity is probably American civil procedure with all its pitfalls, including a possible jury trial in civil cases. ${ }^{129}$ It should come as no surprise that business people mindful of the risk involved in negotiating complex contracts sometimes decide to forego the use of a legally binding contract for their business deals, if that is at all possible. This decision appears to be reasonable, where the risk of nonperformance in the absence of a threat of legal sanctions can be seen as small in proportion to the risks resulting from negotiating an elaborate American-style contract.

But the intent to avoid a legally binding effect will sometimes conflict with the interests of one of the parties in compensation for losses resulting from a frustration of that party's expectations. Even though American courts do in general honor "no-law" and "no-lawyet" clauses, they will occasionally grant relief in disregard of such clauses. Typically, this happens when the defendant's conduct has given rise to a legitimate expectation of legal protection in spite of the transaction's character as a "gentleman's agreement."

129. For details, see Langbein, "Comparative Civil Procedure and the Style of Complex Contracts," 35 Am. J. Comp. L. 381, 385-93 (1987). 
